University of Nebraska - Lincoln

DigitalCommons@University of Nebraska - Lincoln

Faculty Publications: Department of Entomology

1994

\title{
Flight Behavior and Seasonal Trapping of Rhynchophorus cruentatus (Coleoptera: Curculionidae)
}

Thomas J. Weissling

University of Nebraska-Lincoln, tweissling2@unl.edu

Robin M. Giblin-Davis

University of Florida

Barbara J. Center

University of Florida

Tak Hiyakawa

University of Florida

Follow this and additional works at: https://digitalcommons.unl.edu/entomologyfacpub

Part of the Entomology Commons

Weissling, Thomas J.; Giblin-Davis, Robin M.; Center, Barbara J.; and Hiyakawa, Tak, "Flight Behavior and Seasonal Trapping of Rhynchophorus cruentatus (Coleoptera: Curculionidae)" (1994). Faculty Publications: Department of Entomology. 318.

https://digitalcommons.unl.edu/entomologyfacpub/318

This Article is brought to you for free and open access by the Entomology, Department of at DigitalCommons@University of Nebraska - Lincoln. It has been accepted for inclusion in Faculty Publications: Department of Entomology by an authorized administrator of DigitalCommons@University of Nebraska - Lincoln. 


\title{
Flight Behavior and Seasonal Trapping of Rhynchophorus cruentatus (Coleoptera: Curculionidae)
}

\author{
THOMAS J. WEISSLING, ${ }^{1}$ ROBIN M. GIBLIN-DAVIS, ${ }^{2}$ BARBARA J. CENTER, \\ AND TAK HIYAKAWA
}

\begin{abstract}
Fort Lauderdale Research and Education Center, University of Florida, Institute of Food and Agricultural Sciences, 3205 College Avenue, Fort Lauderdale, FL 33314
\end{abstract}

\begin{abstract}
Ann. Entomol. Soc. Am. 87(5): 641-647 (1994)
ABSTRACT Flight behavior, activity, and seasonal variation in capture of Rhynchophorus cruentatus (F.) were investigated. Response of $R$. cruentatus to traps baited with palm tissue was assessed at four locations in Florida over a 12- to 18-mo period. Capture of weevils varied by location and through time. Average temperature, the difference between high and low temperature, and total rainfall during trapping periods were not correlated with seasonal trends, but capture peaked in the spring following rise in temperature. Preflight behaviors of $R$. cruentatus were consistent for all weevils tested. Weevils preparing for flight first wipe their rostrum with the prothoracic legs, pump their pygidium, lift their elytra, and extend their wings. Just before flight, weevils raise the mesothoracic legs above the pronotum. Weevils preparing for a subsequent flight frequently skip the first two preflight events. Studies of flight activity in the laboratory indicate that time of day and feeding status of weevils had no effect on flight. However, flight activity increased with temperature and reduced relative humidity.
\end{abstract}

KEY WORDS Rhynchophorus cruentatus, flight behavior, seasonality

THE GENUS Rhynchophorus is composed of 10 species, seven of which are considered major pests of coconut in production areas (Wattanapongsiri 1966). The only species found in North America is $R$. cruentatus (F.), a relatively large insect (24-33 $\mathrm{mm}$ long) that ranges from the Florida Keys through coastal regions of the southeastern United States (Wattanapongsiri 1966). Unlike several of its congeners, $R$. cruentatus is not a pest of healthy palms but will attack recently transplanted or otherwise stressed palms (Giblin-Davis \& Howard 1989). In Florida, $R$. cruentatus is sympatric with the native cabbage palmetto, Sabal palmetto (Walter) (Woodruff 1967), but also can complete its life cycle in the native saw palmetto, Serrenoa repens (Bartram) (Berger 1907, unpublished data) and in several introduced palm species (GiblinDavis \& Howard 1988).

Although R. cruentatus was once thought to be rare, transplanting of palms for landscaping has probably contributed to an increase in density of the species (Giblin-Davis \& Howard 1988). Despite its apparent population increase, little is known of the biology and ecology of this insect. Volatiles emanating from moribund palms (Chit-

1 Current address: Yakima Agricultural Research Laboratory, USDA-ARS, 3706 W. Nob Hill Boulevard, Yakima, WA 98902.

2 To whom reprint requests should be addressed. tenden 1902, Wattanapongsiri 1966, Weissling et al. 1992, Giblin-Davis et al. 1994) are attractive to adults. In addition, a male-produced aggregation pheromone (5-methyl-4-octanol or "cruentol"), which is synergistic with palm-produced volatiles, may function as a long-range attractant for both males and females (Giblin-Davis et al. 1994, Weissling et al. 1994). Mated females lay eggs in the petiolar bases of leaves or directly into the wounds of stressed or dying host palms, and immature stages usually develop in the crown and distal stem region. The entire life cycle is generally completed in $\approx 84 \mathrm{~d}$ (GiblinDavis \& Howard 1989). Adult activities occur outside the palm, but weevils are cryptic and seek harborage (Chittenden 1902; unpublished data), possibly as a means to conserve body water (Weissling \& Giblin-Davis 1993). The flight activities of $R$. cruentatus are documented poorly, but weevils are known to be present throughout the year (Florida State Department of Plant Industry records; Woodruff 1967). Chittenden (1902) observed weevils flying 5-6 km in response to a dying palm, but no other information is available.

The objectives of this study were to determine changes in seasonal abundance of $R$. cruentatus adults captured in traps, to describe their preflight behaviors, and to determine how tempera- 
ture and relative humidity affect their flight activity.

\section{Materials and Methods}

Seasonal Abundance. Seasonal changes in adult $R$. cruentatus activity or abundance was determined by monitoring capture in traps baited with palm tissue. Four locations in Florida were used, as follows: $2 \mathrm{~km}$ north of the Gainesville airport (northern); $24 \mathrm{~km}$ north of Ochopee in the Big Cypress National Preserve (southwestern); University of Florida, Fort Lauderdale Research and Education Center, Fort Lauderdale (southeastern); and $12 \mathrm{~km}$ south of LaBelle, in Hendry County (south-central). Habitats at each site varied considerably. The Gainesville location primarily is composed of $S$. repens, several hectares of which were removed by plowing 2 mo before termination of the experiment. The Big Cypress National Preserve site is undisturbed, wet prairie, intermixed with stands of S. palmetto, and S. repens. The Fort Lauderdale site is an urban location with a small $S$. palmetto grove ( 31 mature specimens); and the LaBelle site is a 300 -ha pasture with a mix of $S$. palmetto and $S$. repens surrounded by citrus orchards. Four traps constructed of 19-liter black plastic buckets covered with tops made from polyvinyl chloride tubes ( $5 \mathrm{~cm}$ long, $2.4-\mathrm{cm}$ i.d.) glued together longitudinally (Weissling et al. 1992) were placed at each location. These traps prevented escape of captured weevils while the palm tissue harborage improved weevil survival. At all locations except Hendry County, traps were suspended from metal rods $1.2 \mathrm{~m}$ high that were cemented into cinder blocks. Traps at Hendry County were suspended $1.5 \mathrm{~m}$ above the ground from S. palmetto trees. Traps at each site were separated by $20 \mathrm{~m}$. Once every $4-6 \mathrm{wk}$, each trap was baited with $2.5 \mathrm{~kg}$ of fresh, chopped $S$. palmetto stem and crown tissue. Weevils were removed from traps after $1 \mathrm{wk}$, marked by scratching a number or letter on the mesothoracic sternal plate with a dissecting probe, and released $50 \mathrm{~m}$ from the study site. Trapping was conducted at Gainesville from 1 February 1991 to 21 May 1992, at Fort Lauderdale from 10 July 1991 to 7 July 1992, at Big Cypress National Preserve from 31 January 1991 to 2 July 1992, and at Hendry County from 14 June 1991 to 2 July 1992 . To determine if plant phenology was consistent with capture of $R$. $c r u$ entatus, the percentage of $S$. palmetto and $S$. repens with fresh flower spathes, open flowers, fruit, or dead spathes was recorded for each trapping period. Average temperatures and total rainfall during each trapping period were obtained from National Oceanic and Atmospheric Administration (NOAA) records from reporting stations closest to test sites. Pearson-product correlations among weather variables and total cap- ture of $R$. cruentatus adults were calculated using the Statistical Analysis System regression procedure (SAS Institute 1985).

Florida State Department of Plant Industry records from 1956 to 1991 were used to quantify the number of $R$. cruentatus adult indentifications for a historical perspective on seasonal abundance. Average monthly temperatures and rainfall from 1951 to 1981 for the entire state of Florida (NOAA records) were also plotted.

Flight Behavior. $R$. cruentatus adults used in experiments were either collected in the field or reared in the laboratory. Field-collected weevils were trapped in covered buckets as described above. Weevils were separated by sex and maintained on moist tissue paper and sugarcane in 500 -ml plastic cups at $26^{\circ} \mathrm{C}$ until used in experiments. Additional weevils were cultured in the laboratory by the methods of Giblin-Davis et al. (1989).

The sequence of behaviors leading to flight in $R$. cruentatus was investigated. Fifteen weevils of each sex were placed individually on an observation platform (styrofoam block) in a shaded outdoor area and observed during their first and subsequent flights for the following behaviors (previously observed while videotaping flight): wiping of the rostrum with the tibia of the prothoracic legs, pumping of the pygidium, lifting of the elytra, extension of the hind wings, elevation of the mesothoracic legs above the pronotum, and flight. The elytra are held open at a constant angle of about 10 degrees from the longitudinal and horizontal axis. Immediately after weevils took flight, they were captured with an aerial net and placed on the platform for subsequent observation. Temperature and relative humidity during observations averaged $25 \pm 2{ }^{\circ} \mathrm{C}$, and $52.4 \pm$ $2.7 \%$, respectively. Data were converted to the proportion of weevils exhibiting each event for their first and second flights.

The number of flights of $R$. cruentatus adults exposed to low and high humidities, various temperatures, and feeding status was examined at different times of the day to determine what abiotic and biotic factors may affect flight initiation. Tests were conducted in an arena 1.2 by 0.6 by $0.6 \mathrm{~m}$ (length by width by height) constructed of Plexiglas $0.6 \mathrm{~cm}$ thick, enclosed at both ends by window screen. The arena was housed in a room where temperature and humidity were controlled and weevils were exposed to a natural photoperiod. Four temperatures were tested, as follows, $16,20,25$, and $35^{\circ} \mathrm{C}$ at an average relative humidity of $50 \pm 5 \%$. For each temperature, 20-30 males or females were released in the arena at different times of the day $(0800,1000$, 1130 , and 1330 hours EST), given a $30-\mathrm{min}$. acclimation period, and observed for 30-60 min. The number of flights was recorded. This was repeated from three to eight times for each tem- 
perature with fed weevils or weevils deprived of food (sugarcane) for $7 \mathrm{~d}$ before testing.

$R$. cruentatus flight initiation under different humidities was investigated using the same procedures as those for temperature, except that 30 weevils were released and observed for $30 \mathrm{~min}$. This test was conducted four times per humidity treatment with fed weevils at a constant temperature of $35^{\circ} \mathrm{C}$. Humidity in the room housing the flight observation arena was controlled by the addition of a humidifier or dehumidifier and was measured with a hygrometer (model 11-661-7B, Fisher Scientific, Pittsburgh, PA; reported error, $5 \%$ ) at the beginning and end of each observation period. In the high-humidity treatment, relative humidity averaged $77 \pm 0 \%$ compared with $33 \pm$ $1 \%$ for the low-humidity treatment.

Data were converted to the percentage of weevils exhibiting flight, subjected to angular (square root $[x+0.001])$ transformation and analyzed by analysis of variance using the Statistical Analysis System general linear models procedure (SAS Institute 1985). The first experiment tested for differences between fed and starved weevils, and time of day weevils flew. Temperature effects on flight were tested with linear and quadratic contrasts.

\section{Results}

Seasonal Abundance. Total capture of $R$. cruentatus adults in traps baited with $S$. palmetto tissue varied through time and by location (Fig. 1). All locations indicated one period of peak trap capture each year. At all locations except Fort Lauderdale, peak capture occurred in spring to early summer, at or just before the beginning of the wet season. Department of Plant Industry records from 1956 to 1991 also indicated an increase in reports of $R$. cruentatus adults beginning in March, peaking in May, and decreasing through the summer months (Fig. 2). Seasonal air temperatures (averaged from 1951 to 1980 ) began to rise in February, and weevil reports began to increase 1-2 mo before the beginning of the wet season and remained high throughout. Average temperature, the difference between high and low temperatures, and total rainfall during trapping periods in this study were not correlated with total trap capture (Pearson Correlation Coefficient $[P>0.1$ for all variables]). In addition, plant phenology did not indicate trends consistent with seasonal capture. Flowering in $S$. palmetto began as early as April at the Fort Lauderdale site and as late as June at the Gainesville site. Spathes were present through August at all locations. Fruit set started $\approx 1$ mo after first inflorescences were observed, and maturation took $\approx 4-5 \mathrm{mo}$, as described by Brown (1982). For $S$. repens, flowering began in midsummer, and fruit set was observed after $6 \mathrm{wk}$. Two previously marked weevils were recaptured during subse-

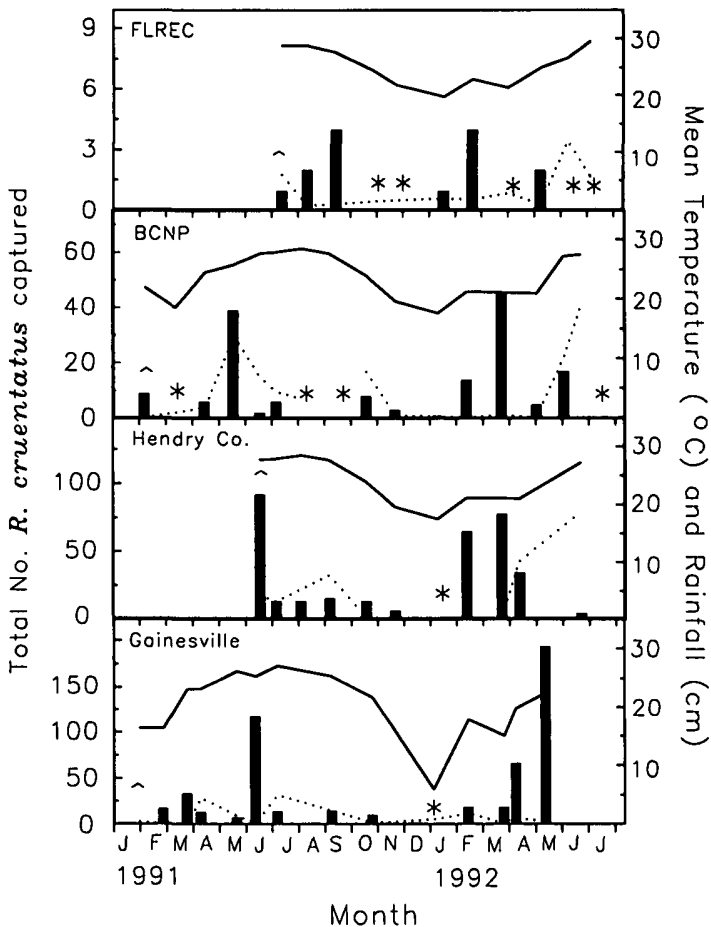

Fig. 1. Seasonal capture of $R$. cruentatus adults (vertical bars) in traps baited with $2.5 \mathrm{~kg}$ chopped $S$. palmetto crown and stem tissue, and mean temperatures (solid line) and total rainfall (dotted line) during trapping periods. Trapping began where indicated by $\leadsto$, and trapping periods where no weevils were captured are indicated by asterisk.

quent trapping: one at Fort Lauderdale on 16 August 1991, and one at Gainesville on 15 June 1991.

Flight Behavior. The sequence of events leading to flight in $R$. cruentatus was similar for weevils beginning their first or second flight (Fig. 3). For the first flight, most weevils first wiped their rostrum and pumped their pygidium before completing subsequent preflight behaviors. Often, weevils preparing for a second flight skipped these first two steps and began preflight behavior by lifting their elytra. Upon takeoff, the mesothoracic legs were raised upward above the pronotum.

No significant differences in flight initiation between male and female weevils were found $(P>0.41$, mean number of flights per weevil \pm SEM: males, $2.4 \pm 0.8$; females, $2.8 \pm 0.9$ ), so data were pooled. In addition, no significant differences in flight between fed or food-deprived weevils $(P>0.08$, mean flights per weevil \pm SEM, averaged across temperatures: fed, $2.2 \pm$ 0.5 ; starved, $3.1 \pm 1.0$ ) or in weevils that flew at different times of day $(P>0.35$, mean flights per weevil \pm SEM, averaged across temperatures, 0800 hours [EST], $1.3 \pm 0.7 ; 1000$ hours [EST], $2.4 \pm 1.2 ; 1130$ hours [EST], $3.6 \pm 1.4 ; 1330$ 


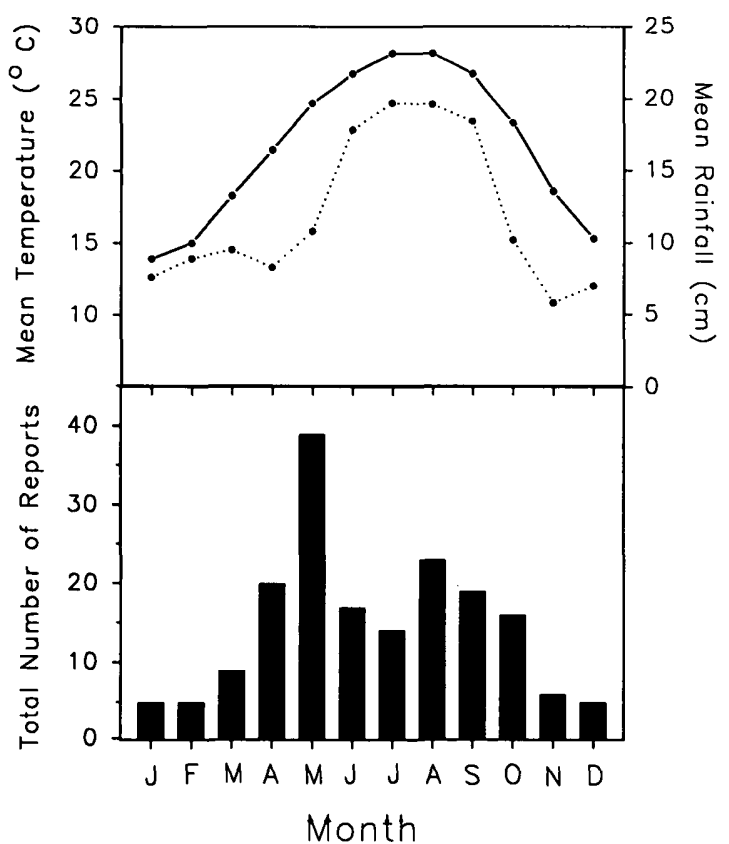

Fig. 2. Florida Department of Plant Industry reports of $R$. cruentatus adults from 1956 to 1991 (bottom), and mean rainfall (dotted line) and temperature (solid line) averaged over entire state from 1951 to 1980 (top).

hours [EST], $3.2 \pm 1.4$ ) were found, so these data were pooled. Temperature had a significant effect on flight initiation. The number of flights per weevil increased quadratically as a function of temperature $(F=10.92 ; \mathrm{df}=1,26 ; P<0.003)$ (Fig. 4). The number of flights per weevil was also significantly greater in the low-humidity treatment than in the high-humidity treatment (means \pm SEM: low humidity, $9.0 \pm 1.1$; high humidity, $4.2 \pm 1.0)(F=35.62$; df $=1,3 ; P<$ $0.01)$.

\section{Discussion}

$R$. cruentatus adults are active fliers and can be found throughout the year in southern Florida (Woodruff 1967; unpublished data). Seasonal variation in the number of $R$. cruentatus captured in palm-baited traps could be a result of season (wet and dry), temperature, population density, or response to palm- or weevil-produced volatiles. Weather variables used in the analyses were not correlated with trap capture. However, data indicate that trap capture increased each spring with rise in average temperature at all sites except Fort Lauderdale (Fig. 1). It is interesting that trap capture peaked 2 mo earlier at Big Cypress National Preserve and 1 mo earlier at Gainesville in 1992 than in 1991. Spring temperatures at those locations also began to increase earlier in 1992 than in 1991. Traps at Fort Lauderdale and Hendry County were not placed early enough in 1991 to estimate spring flight activity.

At this time, an effective method of estimating R. cruentatus population density does not exist. It is therefore difficult to determine if seasonal variation in trap capture is caused by changes in weevil abundance or activity. Although evidence is indirect, we hypothesize that our study measured weevil abundance. Abiotic factors such as temperature and rainfall were similar for the 2- to 3-mo period following peak trap capture. Because $R$. cruentatus adults are long-lived, up to $150 \mathrm{~d}$ in the laboratory (Giblin-Davis et al. 1989), we would have expected high capture levels to continue beyond the peak period if the peak was caused by increased weevil activity alone. In addition, we would have expected to recapture a greater proportion of marked weevils.

Seasonal abundance of the Neotropically distributed R. palmarum (L.) adults, which was also measured by response to palm tissue, is greatest at the end of the wet season and continues at high levels through the dry season (Hagley 1963, Shuiling \& van Dinther 1981, Morales \& Chinchilla 1990, Chinchilla et al. 1991). Temperatures in the tropical locations where tests were conducted do not fluctuate through the season as in Florida. Thus, $R$. palmarum abundance may depend upon rainfall or other factors such as the availability of wounded, diseased, or dying palms. Peak capture of $R$. cruentatus in the spring may represent an emergence of weevils delayed by cooler winter temperatures. Larval development of $R$. cruentatus and pupation are delayed or halted at lower temperatures $\left(23^{\circ} \mathrm{C}\right.$ [Giblin-Davis et al. 1989]), and flight is reduced (Fig. 4). We suspect that lower temperatures also increase the time that adult weevils harbor in their cocoons. As temperatures increase in late winter, weevils at various growth stages within a palm may become synchronous in development and then emerge at about the same time, giving rise to a seasonal population peak. In addition, the 4 or 5 mo of dry fall and winter weather often is extended through April and May (Chen \& Cierber 1990). The rainfall deficit increases stress on palms and may dry out $R$. cruentatus breeding habitats, increasing emergence and activity of weevils. As adults emerge, they colonize a suitable host or harbor within a healthy palm (Weissling \& Giblin-Davis 1993) and may become more difficult to capture with palm-baited traps, or weevils disperse. A weak second peak in late summer (Department of Plant Industry reports; Fig. 2) could represent a partial generation resulting from earliest emerging adults.

A male-produced aggregation pheromone attractive to both male and female $R$. cruentatus was identified (Weissling et al. 1994) $\approx 1$ yr after initiation of the seasonality study. Research has led us to hypothesize that the pheromone acts as a long-range attractant, whereas volatiles re- 


\section{Rhynchophorus cruentatus Males}

First Flight

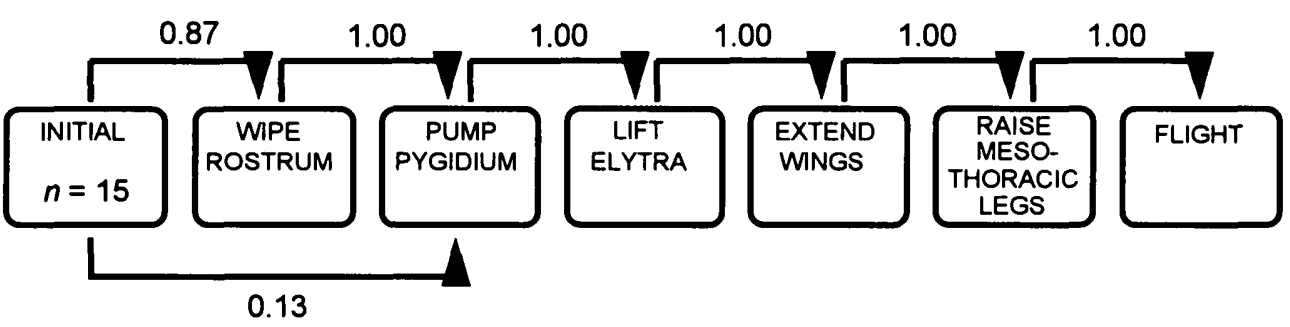

\section{Second Flight}

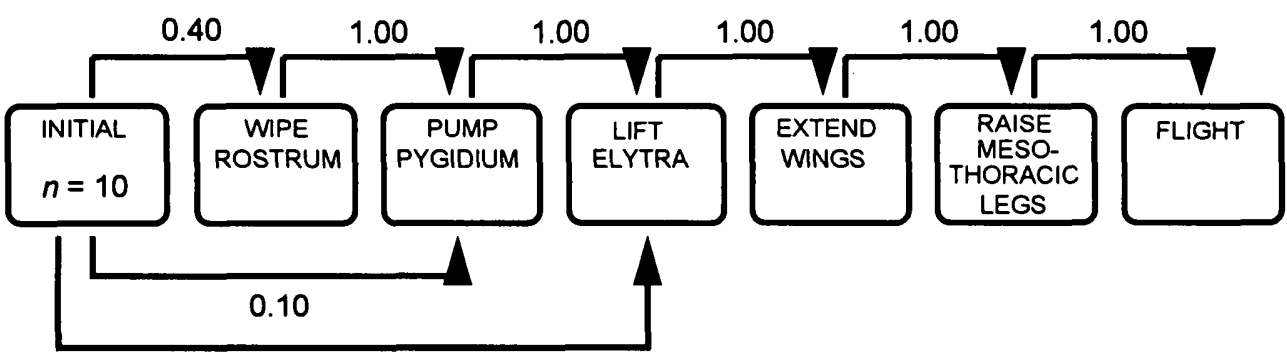

0.50

Rhynchophorus cruentatus Females

First Flight

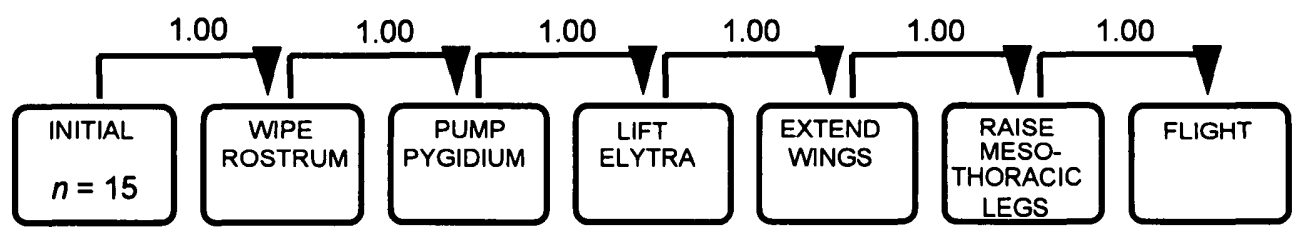

\section{Second Flight}

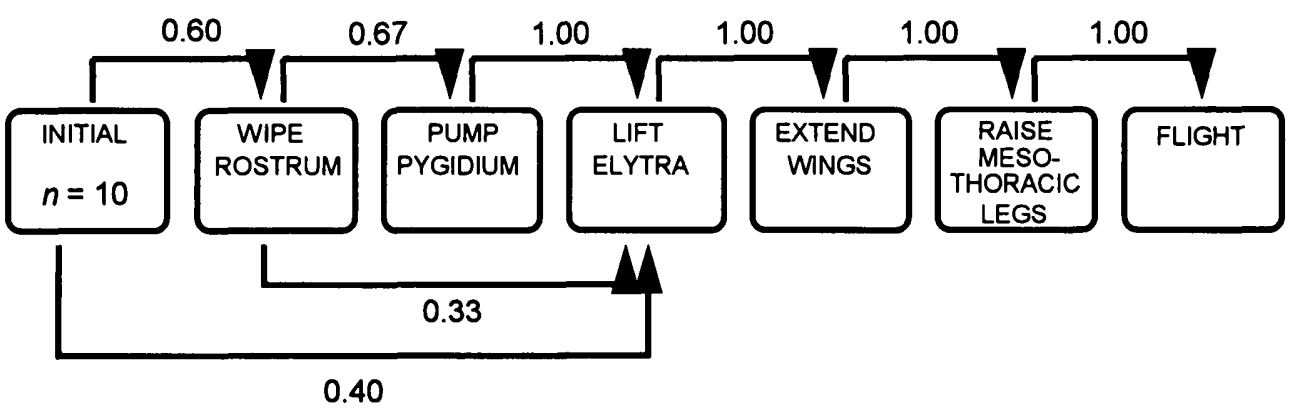

Fig. 3. Ethogram of R. cruentatus male and female flight behavior.

leased from fermenting palm tissue are shortrange attractants (Weissling et al. 1993, 1994). Thus, palm-baited traps are attractive only to weevils that come close, and, once captured, males release pheromone, which increases the effective range of traps. Previous work with the seasonal abundance of $R$. palmarum has demonstrated the same inherent problem. However, because sampling for $R$. palmarum by Hagley (1963), Morales \& Chinchilla (1990), and Chin- 


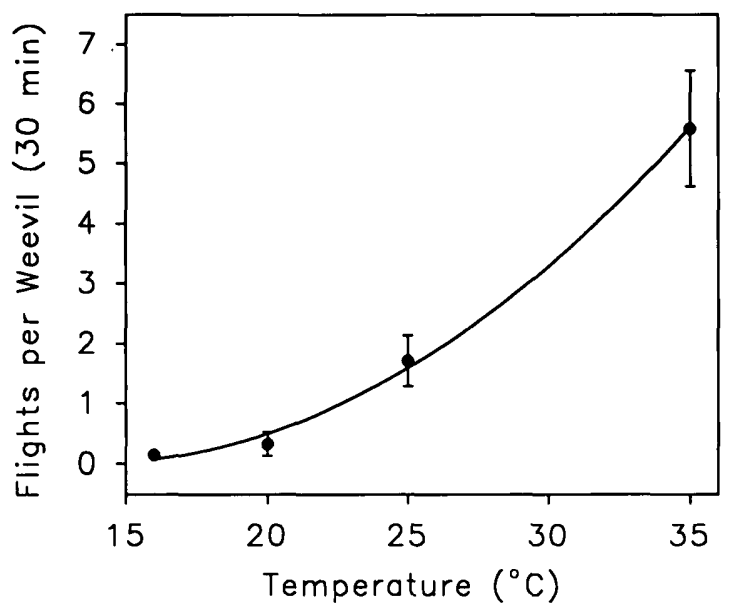

Fig. 4. Flight initiation by $R$. cruentatus at various temperatures.

chilla et al. (1991) was done at daily intervals, the effects of pheromone production would have been potentially less than in our study.

The preflight behaviors of $R$. cruentatus were consistent for all weevils tested. Weevils preparing for their first flight wiped their rostrum and pumped the pygidium. These behaviors were omitted frequently as weevils prepared for subsequent flights (Fig. 3). This suggests that once weevils have flown, they remain in a state of "readiness" to resume flight. As has been observed for many insects (e.g., Sitona cylindricollis Fåhraeus [Hans \& Thorsteinson 1961], $\mathrm{Hy}$ pera postica [Gyllenhal] [Prokopy \& Gyrisco 1965]), R. cruentatus generally does not climb to elevated points to prepare for flight. However, most individuals are ambulatory during the preflight period. In the laboratory, weevils were given only flat surfaces for takeoff, but in the field, released weevils take off directly from the ground or from palm fronds and stems (T.J.W. \& R.M.G.-D., unpublished data). Reasons for elevation of the mesothoracic legs above the pronotum just after the wings are extended and just before and during flight are unclear. Removal of the mesothoracic legs from a few weevils did not prevent flight initiation, even though ambulation was greatly decreased. Metamasius hemipterus sericeus (Olivier), another member of the Rhynchophorinae, also elevates the mesothoracic legs just before and during flight, and the elytra are held at $\approx 40$ degrees from the longitudinal and 20 degrees from the horizontal axis (R.M.G.-D., unpublished data). In many insects, contact of the tarsi with a substrate inhibits flight, and loss of contact initiates wing movement (Johnson 1969). Many insects climb to elevated points or jump to release tarsal contact, and $R$. cruentatus and other members of the Rhynchophorinae may accomplish this by elevation of the mesothoracic legs.
Several factors could affect flight initiation in $R$. cruentatus. Hagley (1965) and Sánchez et al. (1993) observed diel activity patterns in $R$. palmarum. In our study, time of day did not significantly affect flight initiation of $R$. cruentatus, but there was a trend for increased activity through the day. Although not quantified continuously through a full day, weevils have been observed flying in the field at all times from early morning until early evening (T.J.W. \& R.M.G.D., unpublished data). Food deprivation was another factor that did not significantly affect flight activity of $R$. cruentatus. This is contrary to other observations, where starved weevils were more active than nondeprived weevils (Hans \& Thorsteinson 1961, Lopez et al. 1973). R. cruentatus is a large weevil with extensive fat bodies and lives only an average of $10 \mathrm{~d}$ longer with food than without (Giblin-Davis et al. 1989), which may explain the lack of differences.

Two factors that significantly affected flight activity of $R$. cruentatus in the laboratory were temperature and relative humidity. Flight initiation of $R$. cruentatus was greatest at $35^{\circ} \mathrm{C}$. Likewise, Hans \& Thorsteinson (1961) observed that the greatest flight activity of $S$. cylindricollis occurred at $35^{\circ} \mathrm{C}$, but noted a large decrease at $40^{\circ} \mathrm{C}$. We were unable to raise the temperature in the room housing the flight arena above $35^{\circ} \mathrm{C}$, so we have no information about the effects of extreme high temperatures on $R$. cruentatus fight. Weevils exposed to low relative humidity flew almost twice as often as weevils exposed to high humidity, which suggests that humidity may also be an important factor in flight initiation of $R$. cruentatus. Decreased activity of insects under high-humidity conditions has been demonstrated for other insects (e.g., S. cylindricollis [Hans \& Thorsteinson 1961], Cosmopolites sordidus [Germar] [Roth \& Willis 1963]). In our study, the high relative humidity treatment reached only $77 \%$. $R$. cruentatus is a hygric-adapted insect with a high rate of cuticular permeability (Weissling \& Giblin-Davis 1993). For example, at $33 \%$ relative humidity, $R$. cruentatus adults will lose $52 \%$ of their total body water after only $48 \mathrm{~h}$ of exposure. However, R. cruentatus appears to possess hygroreceptors and is capable of perceiving and moving to moisture (Weissling \& Giblin-Davis 1993). Thus, low humidity may be an important stress that initiates flight in $R$. cruentatus as it searches for moister conditions, and high humidity decreases this stress.

Results of this study suggest that $R$. cruentatus is a univoltine insect. At this time, it is unclear what exactly leads to the seasonal peaks observed, but $R$. cruentatus abundance through the season is probably controlled to a great extent by environmental factors such as temperature and rainfall deficit. 


\section{Acknowledgments}

We thank John Cangiamila, Micky Stanaland, and Frank Bilz for technical assistance, A. Duda and Sons for providing S. palmetto trees and research sites, and D. R. Horton and T. D. Center for critically reviewing the manuscript. We are also grateful to the staff of the Big Cypress National Preserve for their cooperation. This research was supported in part by USDA Special Grant in Tropical and Subtropical Agriculture CRSR90-34135-5233 to R.M.G.-D., R. H. Scheffrahn, and J. P. Toth. This is Florida Agricultural Research Station Journal Series R-03705.

\section{References Cited}

Berger, E. W. 1907. The palmetto weevil (Rhynchophorus cruentatus Fab.). Fla. Agric. Exp. Stn. Rep. 1907: XXXIX.

Brown, K. E. 1982 . Observations on the natural history of the cabbage palm, Sabal palmetto. Principes 26: $44-48$.

Chen, E. \& J. F. Gerber. 1990. Climate, pp. 11-34. In R. L. Myers \& J. J. Ewel [eds.], Ecosystems of Florida. University of Central Florida Press, Orlando.

Chinchilla, C., R. Menjívar \& E. Arias. 1991. Picudo de la palma y enfermedad del anillo rojo/hoja pequeña en una plantación comercial en Honduras. Turrialba 40: 471-477.

Chittenden, F. H. 1902. The palm and palmetto weevils. U.S. Dep. Agric. Entomol. Bull. 38: 23-28.

Giblin-Davis, R. M. \& F. W. Howard. 1988. Notes on the palmetto weevil, Rhynchophorus cruentatus (Coleoptera: Curculionidae). Proc. Fla. State Hortic. Soc. 101: 101-107.

1989. Vulnerability of stressed palms to attack by Rhynchophorus cruentatus (Coleoptera: Curculionidae) and insecticidal control of the pest. J. Econ. Entomol. 82: 1185-1190.

Giblin-Davis, R. M., K. Gerber \& R. Griffith. 1989. Laboratory rearing of Rhynchophorus cruentatus and $R$. palmarum (Coleoptera: Curculionidae). Fla. Entomol. 72: 480-488.

Giblin-Davis, R. M., T. J. Weissling, A. C. Oehlschlager \& L. M. Gonzalez. 1994. Field response of Rhynchophorus cruentatus (F.) (Coleoptera: Curculionidae) to its aggregation pheromone and fermenting plant volatiles. Fla. Entomol. 77: 164-177.

Hagley, E.A.C. 1963. The role of the palm weevil, Rhynchophorus palmarum, as a vector of red ring disease of coconuts. I. Results of preliminary investigations. J. Econ. Entomol. 56: 375-380.

1965. On the life history and habits of the palm weevil, Rhynchophorus palmarum. Ann. Entomol. Soc. Am. 58: 22-28.

Hans, H. \& A. J. Thorsteinson. 1961. The influence of physical factors and host plant odour on the induction and termination of dispersal flights in
Sitona cylindricollis Fahr. Entomol. Exp. Appl. 4: 165-177.

Johnson, C. G. 1969. Migration and dispersal of insects by flight. Methuen, London.

Lopez, J. D., Jr., J. A. Witz, A. W. Hartstack, Jr., \& J. P. Hollingsworth. 1973. Response of the male boll weevil to grandlure. Southwest. Entomol. 3: 124129.

Morales, J. L. \& C. Chinchilla. 1990. Picudo de la palma y enfermedad del anillo rojo/hoja pequeña en una plantación comercial en Costa Rica. Turrialba 40: 478-485.

Prokopy, R. J. \& G. G. Gyrisco. 1965. Diel flight activity of migrating alfalfa weevils, Hypera postica (Coleoptera: Curculionidae). Ann. Entomol. Soc. Am. 58: 642-647.

Roth, L. M. \& E. R. Willis. 1963. The humidity behavior of Cosmopolites sordidus (Coleoptera: Curculionidae). Ann. Entomol. Soc. Am. 56: 41-52.

Sánchez, P. A., K. Jaffé, J. V. Hernández \& H. Cerda. 1993. Biologia y comportamiento del picudo del coctero Rhynchophorus palmarum L. (Coleoptera: Curculionidae). Bol. Entomol. Venez. (n.s.) 8: 8393.

SAS Institute. 1985. SAS user's guide: statistics, 5th ed. SAS Institute, Cary, NC.

Schuiling, M. \& J.B.M. van Dinther. 1981. 'Red ring disease' in the Paricatuba oilpalm estate, Para, Brazil. Z. Angew. Entomol. 91: 154-169.

Wattanapongsiri, A. 1966. A revision of the genera Rhynchophorus and Dynamis (Coleoptera: Curculionidae). Dep. Agric. Sci. Bull. (Bangkok) 1: 1-328.

Weissling, T. J. \& R. M. Giblin-Davis. 1993. Water loss dynamics and humidity preference of Rhynchophorus cruentatus (Coleoptera: Curculionidae) adults. Environ. Entomol. 22: 93-98.

Weissling, T. J., R. M. Giblin-Davis, R. H. Scheffrahn \& N. M. Mendoza. 1992. Trap for capturing and retaining Rhynchophorus cruentatus (Coleoptera: Curculionidae) adults using Sabal palmetto as bait. Fla. Entomol. 75: 212-221.

Weissling, T. J., R. M. Giblin-Davis \& R. H. Scheffrahn. 1993. Laboratory and field evidence for male-produced aggregation pheromone in Rhynchophorus cruentatus ( $\mathrm{F}$.) (Coleoptera: Curculionidae). J. Chem. Ecol. 19: 1195-1203.

Weissling, T. J., R. M. Giblin-Davis, G. Gries, R. Gries, A. L. Perez, H. D. Pierce, Jr., \& A. C. Oehlschlager. 1994. An aggregation pheromone of the palmetto weevil, Rhynchophorus cruentatus (F.) (Coleoptera: Curculionidae). J. Chem. Ecol. 20: 505515.

Woodruff, R. E. 1967. A giant palm weevil, Rhynchophorus cruentatus (Fab.), in Florida (Coleoptera: Curculionidae). Fla. Dep. Agric. Div. Plant Ind. Entomol. Circ. 63.

Received for publication 10 March 1994; accepted 2 May 1994. 